\title{
Preference behavior of silver catfish, Rhamdia quelen, juveniles in waters with pH gradients: laboratory experiments
}

\author{
Jaqueline Ineu Golombieski, Alessandra Janaína Becker, Caroline Bruzza Almeida, \\ Ana Paula Gottlieb Almeida and Bernardo Baldisserotto
}

\begin{abstract}
The aim of this study was to determine the preferred $\mathrm{pH}$ in silver catfish Rhamdia quelen juveniles acclimated to different water hardness and the effect of shelters and infection by Ichthyophthirius multifiliis. Fish were acclimated for two weeks at different water hardness levels $\left(4,24,50\right.$, or $\left.100 \mathrm{mg} \mathrm{CaCO}_{3} \mathrm{~L}^{-1}\right)$ and then transferred to a polyethylene tube with a pH gradient ranging from 3.5 to 11.7 and maintaining the same hardness. The position of the fish in the $\mathrm{pH}$ gradient was observed at 1,2, $4,6,8,10$, and $12 \mathrm{~h}$ after transfer. Acclimation to different water hardness did not change $\mathrm{pH}$ preference of uninfected silver catfish (pH 7.30-7.83), and the presence of a shelter at the preferred $\mathrm{pH}$ or outside this preferred $\mathrm{pH}$ did not change the chosen $\mathrm{pH}$ range, either. Consequently silver catfish favored the acid-base regulation over shelter seeking tendency. Juveniles infected with I. multifiliis acclimated to water hardness of $24 \mathrm{mg} \mathrm{CaCO}_{3} \mathrm{~L}^{-1}$ preferred alkaline $\mathrm{pH}$ (9.08-9.79). This choice is not explained by the higher $\mathrm{Na}^{+}$levels at alkaline $\mathrm{pH}$ compared to neutral $\mathrm{pH}$ because infected and uninfected fish choose the same waterborne $\mathrm{Na}^{+}$levels in a $\mathrm{Na}^{+}$gradient with the same $\mathrm{pH}$.
\end{abstract}

O objetivo deste estudo foi determinar o $\mathrm{pH}$ preferencial de juvenis de jundiá Rhamdia quelen aclimatados a diferentes durezas da água e o efeito de abrigos e infecção por Ichthyophthirius multifiliis. Os peixes foram aclimatados durante duas semanas em diferentes níveis de dureza da água $\left(4,24,50 \mathrm{ou} 100 \mathrm{mg} \mathrm{CaCO}_{3} \mathrm{~L}^{-1}\right)$ e então transferidos para um tubo de polietileno com um gradiente de $\mathrm{pH}$ de 3,5-11,7, mantendo a mesma dureza. A posição do peixe no gradiente de $\mathrm{pH}$ foi observada 1, 2, 4, $6,8,10$ e $12 \mathrm{~h}$ após a transferência. A aclimatação a diferentes durezas da água não afetou o $\mathrm{pH}$ preferencial de jundiás não infectados ( $\mathrm{pH} 7,30-7,83$ ), e a presença de um abrigo no $\mathrm{pH}$ preferido ou fora deste $\mathrm{pH}$ também não alterou a faixa de $\mathrm{pH}$ preferida. Portanto, jundiás favorecem a regulação ácido-base em detrimento a uma tendência de procurar abrigo. Em juvenis

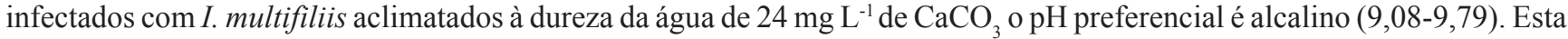
escolha não é explicada pelos maiores níveis de $\mathrm{Na}^{+} \mathrm{em} \mathrm{pH}$ alcalino que em $\mathrm{pH}$ neutro porque peixes infectados e não infectados escolheram os mesmos níveis de $\mathrm{Na}^{+}$na água em um gradiente de $\mathrm{Na}^{+}$com o mesmo $\mathrm{pH}$.

Key words: Behavior, Calcium, Hardness, Ichthyophthirius multifiliis, Shelter.

\section{Introduction}

Water $\mathrm{pH}$ plays an important role in fish homeostasis, development, and survival. Alterations of $\mathrm{pH}$ may cause disturbances in acid-base balance, ion regulation and ammonia excretion (Baldisserotto, 2011). The usual $\mathrm{pH}$ range for fish growth is 6.0 to 9.0 ; lower $\mathrm{pH}$ can occur due to the presence of acidic cations, humic and fulvic acids, and more alkaline $\mathrm{pH}$ can be due to high levels of carbonate and other ions (Parra \& Baldisserotto, 2007). Water quality may elicit a preference or avoidance response in fish (Kroon \& Housefield, 2003), and several studies have demonstrated that fish preferred a specific $\mathrm{pH}$ (Jones et al., 1985; Nakamura, 1986; Peterson et al. 1989; Åtland \& Barlaup 1996; Åtland, 1998; Ikuta et al., 2003; Kroon \& Housefield, 2003, Kroon, 2005, Scott et al., 2005, Riffel et al., 2012).

Silver catfish is the most often raised native species in fish cultures of South Brazil (Baldisserotto, 2009). Several studies determined the best $\mathrm{pH}$ (Zaions \& Baldisserotto, 2000; Lopes et al., 2001; Copatti et al., 2005, 2011a, b) and water hardness (Townsend \& Baldisserotto, 2001; Silva et al., 2003, 2005; Townsend et al., 2003) for survival and growth of this species. The increase of water hardness improves fish survival at very acidic and alkaline environments (Townsend \&

Universidade Federal de Santa Maria, Departamento de Fisiologia e Farmacologia, 97105-900 Santa Maria, Rio Grande do Sul, Brazil. jgolombieski@yahoo.com.br(JIG), alessandra.jbecker@gmail.com(AJB), carolbruzza@hotmail.com(CBA), anapaulagottlieb@hotmail.com (APGA), bbaldisserotto@hotmail.com (BB) 
Baldisserotto, 2001) because $\mathrm{Ca}^{2+}$ stabilizes gill tight junctions and reduces their permeability, reducing diffusive ionic loss to the water (Parra \& Baldisserotto, 2007; Baldisserotto, 2011). However, the effect of $\mathrm{pH}$ on silver catfish growth is altered by water hardness (Copatti et al., 2005, 2011a, 2011b).

Water $\mathrm{pH}$ and hardness also affects infection of silver catfish by the ciliate protozoan Ichthyophthirius multifiliis (Garcia et al., 2011), which causes ichthyophthiriosis, also known as "white spot disease" or "ich", damages gill epithelium and skin, and can cause the death of the host (Miron et al., 2003; Carneiro et al., 2005; Garcia et al., 2007, 2011). Therefore, if available in the fish culture pond, it is possible that fish might choose a specific $\mathrm{pH}$ and/or hardness to reduce the intensity of ich infection. However, there are no studies regarding the preferred $\mathrm{pH}$ in fish acclimated to different water hardness levels or infected by I. multifiliis. Consequently, the objective of this study was to determine the preferred $\mathrm{pH}$ in silver catfish acclimated to different water hardness or infected by I. multifiliis. In addition, as silver catfish is less stressed when in a shelter (Barcellos et al., 2009), an analysis was also made of whether or not the presence of shelters can change the preferred $\mathrm{pH}$.

\section{Material and Methods}

Silver catfish juveniles $(12.40 \pm 1.33 \mathrm{~g}$ and $11.00 \pm 0.29 \mathrm{~cm}-$ total length) were obtained from a fish culture farm near the city of Santa Maria, southern Brazil, and transferred to the Fish Physiology Laboratory at the Universidade Federal de Santa Maria. These juveniles were maintained in continuously aerated (two air pumps of $12 \mathrm{~W}$ each) $250 \mathrm{~L}$ tanks for 15 days for acclimation (temperature: $23 \pm 0.1^{\circ} \mathrm{C}, \mathrm{pH}: 7.1-7.7$, dissolved oxygen levels: $\left.6.9 \pm 0.1 \mathrm{mg} \mathrm{L}^{-1}\right)$. Juveniles were then divided in the following treatments (in $\mathrm{mg} \mathrm{CaCO}_{3} \mathrm{~L}^{-1}$ ): 4, 24, 50, and 100 , and kept for 20 days in continuously aerated $250 \mathrm{~L}$ tanks with the same temperature, $\mathrm{pH}$ and dissolved oxygen conditions than acclimation. A water hardness of $4 \mathrm{mg} \mathrm{CaCO}_{3}$ $\mathrm{L}^{-1}$ was obtained using distilled water, and waterborne $\mathrm{Na}^{+}$, $\mathrm{Cl}^{-}$, and $\mathrm{K}^{+}$levels were adjusted to identical levels of the water with $24 \mathrm{mg} \mathrm{CaCO}_{3} \mathrm{~L}^{-1}$. A water hardness of 50 or $100 \mathrm{mg} \mathrm{CaCO}_{3}$ $\mathrm{L}^{-1}$ was reached by adding $\mathrm{CaCl}_{2} \cdot 2 \mathrm{H}_{2} \mathrm{O}$. The photoperiod was $12 \mathrm{~h}$ light $-12 \mathrm{~h}$ darkness, and the luminosity of the laboratory was 0.6 lux (measured with a LI-COR photometer model LI185B). Juveniles were fed once a day at 8:00 am with a commercial diet (Supra $42 \%$ crude protein, Alisul Alimentos S.A., Carazinho, Brazil) at $5.0 \%$ of their body mass. Residues and feces were siphoned $30 \mathrm{~min}$ after finishing the food, and consequently at least $20 \%$ of the water was replaced with water previously adjusted to the appropriate water hardness. Fish were fasted for $24 \mathrm{~h}$ prior to any experiment.

After acclimation to experimental water hardness each group was transferred to a $6 \mathrm{~m}$ long polyethylene tube containing $50 \mathrm{~L}$ of water, which had been added at one end $0.5 \mathrm{~N}$ sulfuric acid to generate $\mathrm{pH}$ around 3.5 and at the other end $1 \mathrm{~N}$ sodium hydroxide $(\mathrm{NaOH})$ to obtain $\mathrm{pH}$ around 11.7 . The solutions added at the extremities diffused through the water along the tube, creating the $\mathrm{pH}$ gradient, which was maintained by adding the same solutions at the extremities every two hours.

Each group (six replicates per treatment, $\mathrm{N}=5$ each) was placed in the polyethylene tube closest to its acclimation $\mathrm{pH}$. Fish location at the $\mathrm{pH}$ gradient was visually observed at 1,2 , $4,6,8,10$, and $12 \mathrm{~h}$ after the transfer, in order to identify their preferred $\mathrm{pH}$. The $\mathrm{pH}$ was always measured at the location at the moment of the observation. After $12 \mathrm{~h}$ observation the water of the tube was replaced and a new replicate was placed in the tube. Aerators were placed at the tube, and dissolved oxygen levels were maintained at $6.0-6.5 \mathrm{mg} \mathrm{L}^{-1}$. Dissolved oxygen was monitored with an oxygen meter YSI (Y5512, YSI Inc., Yellow Springs, Ohio, USA) every $4 \mathrm{~h}$. The $\mathrm{pH}$ was verified with a DMPH-2 pH meter (Digimed, São Paulo, Brazil) and water hardness by the EDTA titrimetric method (Eaton et al., 2005).

The same experiment was repeated, but with the tube containing a shelter ( $25 \mathrm{~mm}$ diameter tube) placed at the preferred $\mathrm{pH}$ determined in the first experiment. In another series, two shelters were placed at $\mathrm{pH}$ other than preferred one ( $\mathrm{pH} 6.5$ and 8.5 )

In the third experiment, silver catfish infected with $I$. multifiliis were separated into different groups according to their level of infection: $1-20,21-50,51-100$, and 101 or more trophonts/fish. The white spots (trophonts) were counted with the aid of a stereomicroscope (Garcia et al., 2007) in fish anesthetized with eugenol (20 $\left.\mu \mathrm{L} \mathrm{L}^{-1}\right)$ (Cunha et al., 2010). The infected fish were transferred to the polyethylene tube containing the $\mathrm{pH}$ gradient and water hardness of $24 \mathrm{mg} \mathrm{CaCO}_{3}$ $\mathrm{L}^{-1}$. The $\mathrm{pH}$ preference was observed for $12 \mathrm{~h}$.

Silver catfish infected by I. multifiliis preferred an alkaline $\mathrm{pH}$ (see results), and as the alkaline $\mathrm{pH}$ was obtained by adding $\mathrm{NaOH}$, waterborne $\mathrm{Na}^{+}$levels were $50-70 \%$ higher at alkaline $\mathrm{pH}$. Therefore an additional experiment with infected and uninfected fish was carried out in polyethylene tubes with a sodium chloride gradient (adding $\mathrm{NaCl} 0.5 \mathrm{~N}$ at one extremity). Waterborne $\mathrm{Na}^{+}$levels were checked every $2 \mathrm{~h}$ (up to $8 \mathrm{~h}$ ) at the site preferred by the fish. The $\mathrm{Na}^{+}$range in the tube was $1.14 \pm 0.0$ to $7.78 \pm 0.0 \mathrm{mmol} \mathrm{L}^{-1}$, water hardness of $24 \mathrm{mg} \mathrm{CaCO}_{3} \mathrm{~L}^{-1}(\mathrm{pH}$ : $7.76 \pm 0.02$ ). Waterborne $\mathrm{Na}^{+}$levels were determined with a B262 flame spectrophotometer (Micronal, São Paulo, Brazil).

Statistical Analysis. The homogeneity of variances between groups was tested with the Levene test. The comparisons between different treatments were performed by one-way analysis of variance (ANOVA) followed by the Tukey's test using the Software Statistica version 7.0. Data were expressed as mean \pm S.E.M. The minimum significance level was set at $P<0.05$.

\section{Results}

After the silver catfish (infected with I. multifiliis or not) were placed in the polyethylene tubes, they swam along the entire length of the tube (along the $\mathrm{pH}$ gradient), but after about 10 minutes they remained as a shoal at their preferred $\mathrm{pH}$ range up to $12 \mathrm{~h}$ of exposure. 
Acclimation to different water hardness levels did not significantly affect the preferred $\mathrm{pH}$, which was within the 7.30-7.83 range. When the shelter was within the preferred $\mathrm{pH}$ range, fish remained all $12 \mathrm{~h}$ in the shelters. The presence of shelter at the preferred $\mathrm{pH}$ or outside this preferred $\mathrm{pH}$ did not change the chosen $\mathrm{pH}$ range (Table 1), i.e., if the shelter was outside the preferred $\mathrm{pH}$, silver catfish did not use the shelters.

Mortality of silver catfish infected with I. multifiliis was $10 \%$, irrespective of the number of trophonts. Infected fish choose a more alkaline $\mathrm{pH}$ than uninfected fish and those with 21-50 trophonts/fish preferred the highest $\mathrm{pH}$ between the infected fish (Table 2). In the experiment with the $\mathrm{Na}^{+}$ gradient in the tube, silver catfish preferred the $1.14-5.94$ mmol L-1 range, and there was no significant difference between uninfected and infected fish.

\section{Discussion}

Fish in the wild may respond to several environmental factors (Gunn \& Noakes, 1986), and laboratory experiments may separate and clarify these responses (Peterson et al., 1989). Previous study demonstrated that uninfected silver catfish juveniles at water hardness of $24 \mathrm{mg} \mathrm{CaCO}_{3} \mathrm{~L}^{-1}$ preferred the 7.0-7.6 $\mathrm{pH}$ range (Riffel et al., 2012). These results are within the same range observed in the present study for this water hardness, with is in agreement with the fact that juveniles of this species presented better growth at $\mathrm{pH} 7.0$ 7.5 than at pH 5.5 and 9.0 (Baldisserotto, 2011). Survival of silver catfish juveniles in acidic and alkaline water is improved by the addition of $\mathrm{Ca}^{2+}$ to the water (Townsend \& Baldisserotto, 2001), and high water hardness reduced the deleterious effects of acidity ( $\mathrm{pH}$ 5.5) on growth in soft waters (Copatti et al., 2011a). In addition, growth of juveniles maintained at water hardness close to zero was higher at $\mathrm{pH}$ 6.0 than 7.0 and 8.0 (Copatti et al., 2011b). Therefore, as silver catfish growth at different $\mathrm{pH}$ is altered by water hardness, it was expected that the $\mathrm{pH}$ preference could also be altered by adaptation to different water hardness. However, water hardness did not change $\mathrm{pH}$ preference $(\mathrm{pH} 7.30-7.83)$ in this species.

Several others species also showed preference to a specific $\mathrm{pH}$ (Peterson et al., 1989). Japanese fat minnows (Phoxinus lagowski) presented avoidance behavior and their swimming region shifted from $\mathrm{pH} 6.0$ to 7.0 immediately after decreasing $\mathrm{pH}$ and during the exposure to acidic water their swimming activity clearly decreased (Nakamura, 1986). Sockeye salmon (Oncorhynchus nerka), brown trout (Salmo trutta) and

Table 1. Preferred $\mathrm{pH}$ of silver catfish acclimated to different water hardness. Values are reported as mean $\pm \mathrm{SEM}$. Water hardness or the presence of shelter in the tube did not significantly change the preferred $\mathrm{pH}$.

\begin{tabular}{cccc}
\hline \multirow{2}{*}{ Time after transfer $(\mathrm{h})$} & $\begin{array}{c}\text { Polyethylene tube } \\
\text { without shelter }\end{array}$ & \multicolumn{2}{c}{ Tube with shelter } \\
\cline { 3 - 4 } 1 & & Within preferred $\mathrm{pH}$ & Outside preferred $\mathrm{pH}$ \\
\hline & $7.73 \pm 0.22$ & $7.70 \pm 0.09$ & \\
2 & $7.50 \pm 0.10$ & $7.73 \pm 0.61$ & $7.71 \pm 0.07$ \\
4 & $7.63 \pm 0.25$ & $7.75 \pm 0.15$ & $7.70 \pm 0.10$ \\
8 & $7.54 \pm 0.53$ & $7.65 \pm 0.95$ & $7.50 \pm 0.22$ \\
10 & $7.59 \pm 0.78$ & $7.43 \pm 0.48$ & $7.48 \pm 0.28$ \\
12 & $7.77 \pm 0.80$ & $7.80 \pm 0.20$ & $7.77 \pm 0.59$ \\
& $7.72 \pm 0.88$ & $7.85 \pm 0.40$ & $7.70 \pm 0.39$ \\
1 & & $24 \mathrm{mg} \mathrm{CaCO}_{3} \mathrm{~L}^{-1}$ & \\
4 & $7.80 \pm 0.42$ & $7.40 \pm 0.24$ & $7.65 \pm 0.46$ \\
6 & $7.83 \pm 0.51$ & $7.82 \pm 0.24$ & $7.83 \pm 0.28$ \\
8 & $7.57 \pm 0.59$ & $7.58 \pm 0.31$ & $7.48 \pm 0.50$ \\
10 & $7.65 \pm 0.49$ & $7.67 \pm 0.48$ & $7.27 \pm 0.24$ \\
12 & $7.73 \pm 0.39$ & $7.90 \pm 0.50$ & $7.54 \pm 0.58$ \\
1 & $7.73 \pm 0.55$ & $7.84 \pm 0.63$ & $7.89 \pm 0.30$ \\
2 & $7.57 \pm 0.24$ & $7.82 \pm 0.78$ & $7.60 \pm 0.36$ \\
4 & & $50 \mathrm{mg} \mathrm{CaCO} \mathrm{L}^{-1}$ & \\
6 & $7.47 \pm 0.19$ & $7.46 \pm 0.05$ & $7.62 \pm 0.17$ \\
8 & $7.45 \pm 0.55$ & $7.45 \pm 0.54$ & $7.73 \pm 0.14$ \\
10 & $7.58 \pm 0.56$ & $7.63 \pm 0.32$ & $7.50 \pm 0.30$ \\
12 & $7.66 \pm 0.66$ & $7.70 \pm 1.13$ & $7.43 \pm 0.12$ \\
& $7.62 \pm 0.61$ & $7.55 \pm 1.25$ & $7.50 \pm 0.09$ \\
1 & $7.80 \pm 0.51$ & $7.50 \pm 1.40$ & $7.43 \pm 0.29$ \\
2 & $7.83 \pm 0.41$ & $7.60 \pm 0.40$ & $7.40 \pm 0.09$ \\
6 & & $7.68 \pm 0.17$ & \\
8 & $7.55 \pm 0.23$ & $7.70 \pm 0.55$ & $7.58 \pm 0.24$ \\
10 & $7.43 \pm 0.28$ & $7.63 \pm 0.71$ & $7.53 \pm 0.50$ \\
12 & $7.53 \pm 0.41$ & $7.80 \pm 0.47$ & $7.57 \pm 0.57$ \\
& $7.60 \pm 0.21$ & $7.63 \pm 0.23$ & $7.73 \pm 0.37$ \\
& $7.60 \pm 0.21$ & $7.77 \pm 0.28$ & $7.70 \pm 0.06$ \\
& & & $7.63 \pm 0.55$ \\
\hline & & &
\end{tabular}


Table 2. Preferred $\mathrm{pH}$ of silver catfish infected with Ichthyophthirius multifiliis acclimated to water hardness of $24 \mathrm{mg} \mathrm{CaCO}_{3}$ $\mathrm{L}^{-1}$. Values are reported as mean $\pm \mathrm{SEM}$. Means identified by different letters in the rows were significantly different $(P<0.05)$ as determined by ANOVA and Tukey's comparison of mean values.

\begin{tabular}{|c|c|c|c|c|c|}
\hline \multirow{2}{*}{ Time after transfer (h) } & \multirow[b]{2}{*}{ Uninfected } & \multicolumn{4}{|c|}{ Infected fish (trophont/fish) } \\
\hline & & $1-20$ & $21-50$ & $51-100$ & 101 or more \\
\hline 1 & $7.80 \pm 0.42^{b}$ & $9.08 \pm 0.27^{\mathrm{a}}$ & $9.20 \pm 0.24^{\mathrm{a}}$ & $8.33 \pm 0.09^{\mathrm{a}}$ & $8.97 \pm 0.54^{\mathrm{a}}$ \\
\hline 2 & $7.83 \pm 0.51^{b}$ & $9.05 \pm 0.46^{\mathrm{a}}$ & $9.05 \pm 0.25^{\mathrm{a}}$ & $9.27 \pm 0.18^{\mathrm{a}}$ & $9.30 \pm 0.90^{\mathrm{a}}$ \\
\hline 4 & $7.57 \pm 0.59^{\mathrm{b}}$ & $9.08 \pm 0.21^{\mathrm{a}}$ & $8.97 \pm 0.07^{\mathrm{a}}$ & $8.75 \pm 0.15^{\mathrm{ab}}$ & $9.53 \pm 0.68^{\mathrm{a}}$ \\
\hline 6 & $7.65 \pm 0.49^{b}$ & $9.28 \pm 0.32^{\mathrm{a}}$ & $9.43 \pm 0.42^{\mathrm{a}}$ & $9.05 \pm 0.15^{\mathrm{a}}$ & $8.95 \pm 0.05^{\mathrm{a}}$ \\
\hline 8 & $7.73 \pm 0.39^{c}$ & $9.10 \pm 0.25^{b}$ & $10.5 \pm 0.50^{\mathrm{a}}$ & $8.75 \pm 0.50^{\mathrm{b}}$ & $8.40 \pm 0.30^{\mathrm{bc}}$ \\
\hline 10 & $7.73 \pm 0.55^{\mathrm{c}}$ & $9.03 \pm 0.29^{b}$ & $10.8 \pm 0.00^{\mathrm{a}}$ & $9.80 \pm 0.50^{\mathrm{b}}$ & $9.35 \pm 0.25^{\mathrm{b}}$ \\
\hline 12 & $7.57 \pm 0.24^{\mathrm{c}}$ & $9.10 \pm 0.23^{b}$ & $10.6 \pm 0.00^{\mathrm{a}}$ & $9.60 \pm 0.20^{\mathrm{b}}$ & $9.45 \pm 0.45^{\mathrm{b}}$ \\
\hline Overall mean & $7.70 \pm 0.46^{c}$ & $9.10 \pm 0.29^{b}$ & $9.79 \pm 0.18^{a}$ & $9.08 \pm 0.19^{b}$ & $9.14 \pm 0.45^{b}$ \\
\hline
\end{tabular}

Japanese trout (Salvelinus leucomaenis) showed inhibition of digging and swimming behavior in slightly acidic (5.8-6.4) compared to neutral water (6.8-7.1) (Ikuta et al., 2003). Juvenile brook trout (Salvelinus fontinalis) avoided $\mathrm{pH} 4.0,5.0$ and 5.5 and these acidic $\mathrm{pH}$ values affected social interactions (Pedder \& Maly, 1986). Common carp (Cyprinus carpio) and goldfish (Carassius auratus) avoided $\mathrm{pH}$ values within the 5.5-7.0 range with preference to $\mathrm{pH} 8.4$ and 7.2, respectively (Ishio, 1965).

Silver catfish remained in the shelters when they were within the preferred $\mathrm{pH}$. This result is in accordance with the fact that the presence of a shelter in the tank reduced whole body plasma cortisol peak values and their duration in previously stressed silver catfish (Barcellos et al., 2009). Shelter seeking tendencies were also observed in channel catfish Ictalurus punctatus (Brown et al., 1970). The presence of the shelter provided a darkened refuge that, most likely, created a more comfortable environment and allowed a fast recovery from stress (Britz \& Piennar, 1992) and better growth rates in African catfish, Clarias gariepinus (Hossain et al., 1998). However, when the shelters were outside the preferred $\mathrm{pH}$ range, silver catfish did not use them. Therefore, silver catfish prefer a certain $\mathrm{pH}$ over shelter seeking tendency.

Silver catfish infected by I. multifiliis showed preference for a more alkaline $\mathrm{pH}(9.08$ - 9.79) than uninfected fish $(\mathrm{pH}$ 7.70). This result is unexpected, since infected silver catfish presented higher mortality at this water hardness when maintained at pH 9.0 than at $\mathrm{pH} 5.0$ (Garcia et al., 2011). As there was a gradual reduction of "white spots" in silver catfish infected by I. multifiliis using $\mathrm{NaCl}\left(786 \mathrm{mmol} \mathrm{L}^{-1} \mathrm{Na}^{+}\right.$) (Miron et al.,2003), it was hypothesized that infected fish preferred the alkaline $\mathrm{pH}$ due to the higher $\mathrm{Na}^{+}$levels at this $\mathrm{pH}$, compared with neutral $\mathrm{pH}$. Fish would choose the site where the infection would be reduced due to the higher salt concentration. However, there was no difference in the range of $\mathrm{Na}^{+}$levels chosen by infected and uninfected fish. Therefore, the reason for infected silver catfish to choose alkaline $\mathrm{pH}$ remained to be studied.

In conclusion, the results indicated that acclimation to different water hardness did not change $\mathrm{pH}$ preference of uninfected silver catfish ( $\mathrm{pH}$ 7.30-7.83), and the presence of shelter at the preferred $\mathrm{pH}$ or outside this preferred $\mathrm{pH}$ did not change the chosen $\mathrm{pH}$ range. Consequently silver catfish prefer a certain $\mathrm{pH}$ over shelter seeking tendency. Juveniles infected with I. multifiliis acclimated to water hardness of $24 \mathrm{mg} \mathrm{CaCO}_{3}$ $\mathrm{L}^{-1}$ preferred alkaline $\mathrm{pH}$ (9.03-9.79). This choice is not explained by the higher $\mathrm{Na}^{+}$levels at alkaline $\mathrm{pH}$ compared to neutral $\mathrm{pH}$ because infected and uninfected fish chose the same waterborne $\mathrm{Na}^{+}$levels in a $\mathrm{Na}^{+}$gradient with the same $\mathrm{pH}$.

\section{Acknowledgments}

B. B. was granted a research fellowship and A. J. B., C. B. A., and A. P. G. A. were granted undergraduate fellowships from $\mathrm{CNPq}$ (Conselho Nacional de Desenvolvimento Científico e Tecnológico, Brazil). This study was approved by the Ethics Committee on Animal Experimentation of UFSM under registration number 24/2007.

\section{Literature Cited}

Åtland, A. 1998. Behavioral responses of brown trout, Salmo trutta, juveniles in concentration gradients of $\mathrm{pH}$ and $\mathrm{Al}$ - a laboratory study. Environmental Biology of Fishes, 53: 331-345.

Åtland, A. \& B. T. Barlaup. 1996. Avoidance behavior of Atlantic salmon (Salmo salar L.) fry in waters of low $\mathrm{pH}$ and elevated aluminum concentration: laboratory experiments. Canadian Journal of Fisheries and Aquatic Science, 53: 1827-1834.

Baldisserotto, B. 2009. Piscicultura continental no Rio Grande do Sul: situação atual, problemas e perspectivas para o futuro. Ciência Rural, 39: 291-299.

Baldisserotto, B. 2011. Water pH and hardness affect growth of freshwater teleosts. Brazilian Journal of Animal Science, 40: 138-144.

Barcellos, L. J. G., L. C. Kreutz, R. M. Quevedo, J. G. S. Rosa, G. Koakoski, L. Centenaro \& E. Pottker. 2009. Influence of color background and shelter availability on jundiá (Rhamdia quelen) stress response. Aquaculture, 288: 51-56.

Britz, P. J. \& A. G. Piennar. 1992. Laboratory experiments on the effect of light and cover on the behaviour and growth of African catsh, Clarias gariepinus (Pisces: Clariidae). Jornal of Zoology, 227: 43-62.

Brown, B. E., I. Inman \& A. Jearld Jr. 1970. Schooling and shelter seeking tendencies in fingerling channel catfish. Transactions of the American Fisheries Society, 99: 540-545.

Carneiro, P. C. F., E. Schorer \& J. D. Mikos. 2005. Conventional therapeutic treatments on the control of the parasite 
Ichthyophtirius multifiliis in Rhamdia quelen. Pesquisa Agropecuária Brasileira, 40: 99-102.

Copatti, C. E., I. J. Coldebella, J. Radünz Neto, L. O. Garcia, M. C. Rocha \& B. Baldisserotto. 2005. Effect of dietary calcium on growth and survival of silver catfish fingerlings, Rhamdia quelen (Heptapteridae), exposed to different water $\mathrm{pH}$. Aquaculture Nutrition, 11: 345-350.

Copatti, C. E., L. O. Garcia, M. A. Cunha, B. Baldisserotto \& D. Kochhann. 2011a. Interaction of water hardness and $\mathrm{pH}$ on growth of silver catfish, Rhamdia quelen, juveniles. Journal of the World Aquaculture Society, 42: 580-585.

Copatti, C. E., L.O. Garcia, D. Kochhann, M. A. Cunha, A. G. Becker, B. Baldisserotto. 2011b. Low water hardness and $\mathrm{pH}$ affect growth and survival of silver catfish juveniles. Ciência Rural, 41: 1482-1487.

Cunha, M. A. da, C. C. Zeppenfeld, L. O. Garcia, V. L. Loro, M. B. Fonseca, T. Emanuelli, A. P. L Veeck, C. E. Copatti \& B. Baldisserotto. 2010. Anesthesia of silver catfish with eugenol: time of induction, cortisol response and sensory analysis of fillet. Ciência Rural, 40: 2107-2114.

Eaton, A. D., L. S. Clesceri, E. W. Rice \& A. E. Greenberg. 2005. Standard methods for the examination of water and wastewater. $21^{\text {st }}$ ed, Springfield: American Public Health Association.

Garcia, L. O., A. G. Becker, C. E. Copatti, J. Radünz Neto \& B. Baldisserotto. 2007. Salt in the food and water as a supportive therapy for Ichthyophthirius multifiliis infestation on silver catsh, Rhamdia quelen, ngerlings. Journal of the World Aquaculture Society, 38: 1-11.

Garcia, L. O., A. G. Becker, M. A. Cunha \& B. Baldisserotto. 2011. Effects of water $\mathrm{pH}$ and hardness on infection of silver catsh, Rhamdia quelen, fingerlings by Ichthyophthirius multifiliis. Journal of the World Aquaculture Society, 42: 399-405.

Gunn, J. M. \& D. L. G. Noakes. 1986. Avoidance of low pH and elevated Al concentrations by brook charr (Salvelinus fontinalis) alevins in laboratory tests. Water, Air and Soil Pollution, 30: 497-503.

Hossain, M. A. R., M. C. M. Beveridge \& G. S. Haylor. 1998. The effects of density, light and shelter on the growth and survival of African catsh (Clarias gariepinus Burchell, 1822) ngerlings. Aquaculture, 160: 251-258.

Ikuta, K., Y. Suzuki \& S. Katimura. 2003. Effects of low pH on the reproductive behavior of salmonid shes. Fish Physiology and Biochemistry, 28: 407-410.

Ishio, S. 1965. Behavior of fish exposed to toxic substances. Proceedings International Conference on Intelligent Systems for Molecular Biology, 1: 19-40.

Jones, K. A., T. J. Hara \& E. Sherer. 1985. Behavioral modifications in Arctic char (Salvelinus alpinus) chronically exposed to sublethal pH. Physiological Zoology, 58: 400-412.

Kroon, F. J. \& G. P. Housefield. 2003. A fluviarium with controlled water quality for preference - avoidance experiments with fish and invertebrates. Limnology and Oceanography: Methods, 1: 39-44.

Kroon, F. J. 2005. Behavioural avoidance of acidified water by juveniles of four commercial fish and prawn species with migratory life stages. Marine Ecology Progress Series, 285: 193204.

Lopes, J. M., L. V. F. Silva \& B. Baldisserotto. 2001. Survival and growth of silver catfish larvae exposed to different water $\mathrm{pH}$. Aquaculture International, Holanda, 9: 73-80.

Miron, D. S., L. V. F. Silva, J. I. Golombieski \& B. Baldisserotto. 2003. Efficacy of different salt $(\mathrm{NaCl})$ concentrations in the treatment of Ichthyophthirius multifiliis contamination of silver catsh, Rhamdia quelen, ngerlings. Journal of Applied Aquaculture, 14: 155-161.

Nakamura, F. 1986. Avoidance behavior and swimming activity of fish to detect $\mathrm{pH}$ changes. Bulletin of Environmental Contamination and Toxicology, 37: 808-815.

Parra, J. E. G. \& B. Baldisserotto. 2007. Effect of water pH and hardness on survival and growth of freshwater teleosts. Pp.135150. In: Baldisserotto, B., J. M. Mancera \& B. G. Kapoor (Eds.). Fish osmoregulation. New Hampshire, Science Publishers.

Pedder, S. C. J. \& E. J. Maly. 1986. The avoidance response of groups of juvenile brook trout, Salvelinus fontinallis, to varying levels of acidity. Aquatic Toxicology, 8: 111-119.

Peterson, R. H., K. Coombs, J. Power \& U. Paim. 1989. Responses of several fish species to $\mathrm{pH}$ gradients. Canadian Journal of Zoology, 67: 1566-1572.

Riffel, A. P. K, S. Jardim, M. C. Pires, B. Bertagnolli, B. R. S. Corrêa, F. C. Ré, F. M. B. Zambra, G. Lubini, L. O. Garcia \& B. Baldisserotto. 2012. Preferred $\mathrm{pH}$ of silver catfish Rhamdia quelen acclimated to different $\mathrm{pH}$ levels. Ciência Rural, 42: 834-836.

Scott, D. M., M. C. Lucas \& R. W. Wilson. 2005. The effect of high $\mathrm{pH}$ on ion balance, nitrogen excretion and behaviour in freshwater sh from an eutrophic lake: A laboratory and field study. Aquatic Toxicology, 73: 31-43.

Silva, L. V. F., J. I. Golombieski \& B. Baldisserotto. 2003. Incubation of silver catfish, Rhamdia quelen (Pimelodidae), eggs at different calcium and magnesium concentrations. Aquaculture, 228: 279287.

Silva, L. V. F., J. I. Golombieski \& B. Baldisserotto. 2005. Growth and survival of silver catfish larvae, Rhamdia quelen (Heptapteridae), at different calcium and magnesium concentrations. Neotropical Ichthyology, 3: 299-304.

Townsend, C. R. \& B. Baldisserotto. 2001. Survival of silver catfish juveniles exposed to acute changes of water $\mathrm{pH}$ and hardness. Aquaculture International, 9: 413-419.

Townsend, C. R., L. V. F. Silva \& B. Baldisserotto. 2003. Growth and survival of Rhamdia quelen (Siluriformes, Pimelodidae) larvae exposed to different levels of water hardness. Aquaculture, 215: 103-108.

Zaions, M. I. \& B. Baldisserotto. 2000. $\mathrm{Na}^{+}$and $\mathrm{K}^{+}$body levels and survival of fingerlings of Rhamdia quelen (Siluriformes: Pimelodidae) exposed to acute changes of water $\mathrm{pH}$. Ciência Rural, 30: 1041-1045.

Submitted December 10, 2012 Accepted May 25, 2013 by Adalberto Val Published September 30, 2013 